\title{
Kemampuan Penerapan Struktur Esai Pada Tulisan Mahasiswa Universitas Katolik Musi Charitas
}

\author{
Katarina Retno Triwidayatia,1, Tresiana Sari Diah Utami ${ }^{\mathrm{a}, 2}$ \\ anniversitas Katolik Musi Charitas, Palembang, Indonesia
}

${ }^{1}$ retno@ukmc.ac.id; ${ }^{2}$ tresiana@ukmc.ac.id

\begin{tabular}{l} 
Article info \\
\hline Article history: \\
Received: $29-08-2019$ \\
Revised : 30-04-2020 \\
Accepted: 13-05-2020
\end{tabular}

Keywords:

essays

literacy

pen and paper-based text writing

\author{
A B S T R A C T
}

Literacy must not only be mastered by school children, but also by students. This study aims to determine the level of student literacy. This article aims to describe the ability to apply essay writing, specifically the application of the structure of essays to the writings of students from the conversion of the Catholic University of Musi Charitas. This research This study uses a mixed-method (qualitative and quantitative). Also, this study refers to a descriptive approach. Data collection techniques used in this study are pen and paper-based text. This technique is done by giving written text to the students being studied. The research sample of 180 writings randomly. The data obtained were validated using the researcher triangulation mode. The results showed that categorized as low writings obtained scores ranging from 1.67-30 as many as 58 writings or $32.2 \%$, categorized writings received a score of 50 as many as 100 writings or $55.5 \%$, and capable categories were as many as 22 writings or $12.2 \%$ who received scores ranging from 88.3-100.

Literasi tidak hanya harus dikuasai oleh anak sekolah, tetapi juga oleh mahasiswa. Penelitian ini bertujuan mengetahui tingkat literasi menulis mahasiswa. Artikel ini bertujuan mendeskripsikan kemampuan penerapan penulisan esai, terkhusus penerapan struktur esai pada tulisan hasil konversi mahasiswa Universitas Katolik Musi Charitas. Penelitian ini Penelitian ini menggunakan mix method (kualitatif dan kuantitatif). Selain itu, penelitian ini juga mengacu pada pendekatan deskriptif. Teknik pengumpulan data yang digunakan pada penelitian ini adalah pen and paper based teks. Teknik ini dilakukan dengan cara memberikan teks menulis pada mahasiswa yang diteliti. Sampel penelitian sebanyak 180 tulisan secara acak. Data yang diperoleh divalidasi dengan menggunakan modus triangulasi peneliti. Hasil penelitian menunjukkan tulisan yang dikategorikan rendah memperoleh skor bekisar $1.67-30$ sebanyak 58 tulisan atau $32.2 \%$, tulisan yang dikategorikan mendapatkan skor 50 sebanyak 100 tulisan atau $55.5 \%$, dan kategori mampu sebanyak 22 tulisan atau $12.2 \%$ yang mendapatkan skor berkisar 88.3-100.

Copyright (C) 2020 Institut Agama Islam Negeri Syekh Nurjati Cirebon.

\section{PENDAHULUAN}

Terdapat empat keterampilan yang harus dikuasai dalam pembelajaran bahasa Indonesia. Keempat keterampilan tersebut antara lain menyimak, berbicara, membaca, dan menulis. Keempat keterampilan tersebut terbagi menjadi keterampilan yang reseptif dan produktif. Keterampilan menyimak dan membaca 
melatih seseorang untuk mendapatkan informasi atau pesan yang terdapat dalam tulisan. Pendengar atau pembaca mendapatkan informasi tanpa menghasilkan suatu produk bacaan baru. Oleh sebab itu, keterampilan menyimak dan membaca termasuk ke dalam keterampilan reseptif. Adapun keterampilan berbicara dan menulis termasuk ke dalam keterampilan produktif. Kedua keterampilan tersebut melatih pembicara dan penulis untuk menghasilkan suatu produk, baik berupa teks atau tulisan.

Keterampilan menulis sering dianggap sebagai keterampilan yang paling kompleks (Mariana, 2013). Keterampilan menulis merupakan keterampilan berbahasa paling akhir yang dikuasai oleh seseorang setelah menguasai keterampilan menyimak, berbicara, dan membaca. Keterampilan menulis juga bukanlah sekadar keterampilan menyalin kata, frasa, ataupun kalimat, melainkan juga keterampilan dalam mengembangkan dan menuangkan pikiran penulis dalam suatu struktur tulisan yang teratur dan tepat. Karena diaggap sebagai keterampilan yang paling kompleks, banyak tulisan meniru atau mem-plagiat hasil karya orang lain. Plagiasi terjadi dikarenakan pembaca yang tidak memiliki referensi bacaan untuk ditulis.

Penelitian Aji (2013) menunjukkan bahwa 95,71\% mahasiswa tidak menyadari telah melakukan plagiarisme. Mahasiswa membaca dan menyalin informasi yang didapat tanpa mencantumkan sumber data atau informasi yang diperoleh. Adapun alasan melakukan plagiarisme adalah agar kegiatan menulis lebih cepat dengan usaha yang ringan. Plagiasi dapat terjadi karena kemampuan literasi menulis yang rendah. Hal tersebut senada dengan pernyataan bahwa budaya literasi diarahkan untuk melakukan kebiasaan berpikir. Kebiasaan berpikir tersebut diwujudkan dengan kegiatan membaca dan menulis yang akhirnya akan menghasilkan suatu karya (Muslimin, 2018).

Pemerintah melalui Kementerian Pendidikan dan Kebudayaan (Kemendikbud) mencoba membuat solusi tersebut, yaitu dengan membuat suatu gerakan bernama Gerakan Literasi Bangsa (GLB). Gerakan Literasi Bangsa dibuat dengan tujuan menumbuhkan budi pekerti remaja melalui budaya literasi membaca dan menulis. Dalam program tersebut, pemerintah berupaya menumbuhkan kesadaran kepada remaja melalui kebijakan atau kebiasaan membaca selama 15 menit sebelum proses pembelajaran dimulai atau dalam sehari minimal 15 menit melakukan kegiatan membaca. Dalam kegiatan literasi membaca diharapkan pembaca mampu bernalar dan memahami isi bacaan sehingga mampu membantu kegiatan menulis menjadi lebih mudah. Hal ini senada dengan hasil penelitian yang menunjukkan bahwa kemampuan menulis masih rendah karena budaya baca dan budaya nalar yang belum baik (Hasnadi, 2019).

Salah satu faktor penentu keberhasilan dalam pembelajaran adalah model yang digunakan (Mulyaningsih, dkk, 2016). Penguasaan keempat keterampilan bahasa dapat dilakukan dengan pemilihan pendekatan pembelajaran yang tepat. Salah satunya dengan menggunakan pendekatan berbasis teks (genre based approach). Pendekatan ini melaksanakan pembelajaran bahasa dikaitkan dengan berbagai teks. Pendekatan ini bertujuan memperkenalkan sebanyak mungkin jenis dan karakter teks kepada peserta didik. Hal ini berarti kegiatan memahami hingga mengkreasi teks dilaksanakan dengan berbagai teks. Salah satu kegiatan pembelajaran yang dapat dilaksanakan berdasarkan pendekatan tersebut adalah dengan kegiatan mengonversi teks. Dalam kegiatan mengonversi teks, peserta 
didik menghasilkan teks yang berbeda dari sebelumnya. Dalam kegiatan mengonversi teks ini, peserta didik dituntut memahami struktur teks asli dan strukur teks yang akan dikonversi dengan tetap memperhatikan topik utama yang akan ditulis dan memahami konsep dasar struktur teks yang diujikan.

Salah satu bentuk teks adalah esai. Esai merupakan sebuah karangan atau tulisan dalam bentuk prosa. Esai dalam pengertian umum adalah sebuah pembahasan secara prosa dari gagasan atau pikiran yang masih terpenggalpenggal. Esai ialah sepenggal sastra prosa yang ditulis untuk memberikan suatu eksposisi yang bersifat pribadi terhadap suatu subjek (Parera dalam Fitriyani, 2016). Struktur esai minimal mencakup tiga bagian: pendahuluan, isi, dan penutup (Hidayanto, 2019). Hal ini diperkuat oleh pendapat Nugraheni (2017) bahwa struktur tulisan esai mutlak harus ada dalam sebuah tulisan, minimal terdiri atas lima paragraf. Paragraf pertama berisi perkenalan topik yang akan dibahas. Paragraf kedua sampai dengan keempat atau yang disebut tubuh esai yang berisi kalimat pendukung tesis atau argumen-argumen penulis dan disertai dengan bukti-bukti yang memadai. Paragraf terakhir berisi kesimpulan.

Penelitian yang dilakukan Havana dan Krismayani berfokus pada aspek kompetensi literasi digital terutama dalam kemampuan internet searching yaitu memanfaatkan search engine dalam pencarian informasi, memahami internet sebagai sumber informasi dan penghubung serta memanfaatkan internet untuk melakukan beberapa aktivitas (Havana, 2014). Yaumi (2017) melakukan penelitian yang berfokus dalam penerapan model Model Discovery Learning dalam melatih kemampuan literasi menulis sains peserta didik kelas VII SMP. Berbeda dengan penelitian sebelumnya, penelitian ini bertujuan mendeskripsikan kemampuan mahasiswa Universitas Katolik Musi Charitas dalam menuliskan struktur tulisan esai dengan tepat. Oleh karena itu, artikel ini difokuskan pada pembahasan mengenai kemampuan menulis struktur esai.

\section{METODE}

Penelitian ini dilaksanakan di Universitas Katolik Musi Charitas pada tahun ajar 2018/2019. Data dikumpulkan bersumber dari tulisan mahasiswa yang menempuh Mata Kuliah Wajib Umum (MKWU) Bahasa Indonesia pada saat semester ganjil dan genap. Jumlah teks tersebut adalah 382 tulisan dan kemudian diambil 180 teks secara acak sebagai sampel penelitian. Pendekatan kualitatif mengacu pada penelitian yang ditujukan untuk menganalisis data, baik secara fenomenologi ataupun naturalistis (Sarwono dalam Afifuddin \& Saebani, 2009).

Instrumen pengumpulan data adalah alat bantu yang dipilih atau digunakan dalam kegiatan mengumpulkan data sehingga kegiatan tersebut menjadi sistematis dan mudah. Instrumen penelitian ini adalah tes berupa menulis teks argumentasi (esai) sebanyak 3 paragraf. Bentuk konkrit pengumpulan data penelitian ini adalah dengan pemberian pretes kepada mahasiswa yang mengambil mata kuliah Bahasa Indonesia. Mahasiswa tersebut diberi tes berupa pemberian teks berita. Teks berita tersebut kemudian dikonversikan menjadi teks argumentatif (Widiastuti, 2020). Teknis penelitiannya dimulai dengan tidak memberikan penjelasan atau pemberian informasi apapun mengenai hal tersebut karena struktur dan kaidah penulisan kedua teks tersebut seharusnya sudah dipahami mahasiswa di tingkat pendidikan sebelumnya.

Teknik analisis dilakukan dengan pengorganisasian data, menguji asumsi atau permasalahan yang ada terhadap data, mencari alternatif penjelasan bagi data. 
Data yang diperoleh diolah dengan cara memberikan skoring pada indikator: kemampuan konversi teks, struktur tulisan atau esai, spesifikasi topik, dan kebahasaan. Namun, dalam artikel ini, kemampuan penerapan struktur esai dibahas lebih spesifik.

Data yang diperoleh divalidasi dengan menggunakan modus triangulasi peneliti. Metode triangulasi peneliti dipilih karena masing-masing peneliti mempunyai kejelian atau ketelitian dalam menilai yang berbeda-beda. Oleh sebab itu, triangulasi peneliti digunakan pada penelitian ini yaitu pengecekan oleh dua orang mengenai hasil penilaian yang telah didapatkan. Hasil penilaian yang telah dilakukan oleh dua penilai direrata dan dipersentasekan untuk mengetahui kemampuan mahasiswa dalam megonversi teks.

Dalam menganalisa data, langkah-langkah menganalisis data, (1) peneliti pertama mengoreksi esai yang telah dibuat dengan cara membaca teks dan memberikan penilaian dalam menentukan struktur esai yang telah dibuat. (2) selanjutnya peneliti kedua juga melakukan penilaian terhadap struktur esai tersebut. (3) Hasil koreksi atau penilaian dari kedua peneliti atau penilai dilihat persamaan dalam penilaian esai tersebut. (3) Nilai yang didapat dari dua validator akan ditentukan rerata dan persentasenya. Kedua validator merupakan dosen Bahasa Indonesia yang ahli dalam bidang penulisan.

Penilaian dilakukan melalui skoring. Setiap bagian atau struktur penulisan esai mendapatkan skor 1 untuk setiap validator. Masing-masing validator akan menilai struktur tulisan dengan skor maksimal 3. Penilaian akan dikategorikan menjadi kurang, sedang, dan mampu disesuaikan dengan skor yang diperoleh.

Dalam melakukan penilaian, penilai atau validator mengacu terhadap teori struktur esai. Esai yang baik idealnya terdiri dari tiga bagian. Tiga bagian esai antara lain, pengantar/pendahuluan, paragraf isi, dan paragraf penutup (Wijayanti $\mathrm{dkk}$, 2015). Paragraf pendahuluan berisi latar belakang informasi singkat mengenai topik yang akan dibicarakan dalam esai. Paragraf pernyatan dimulai dengan pernyataan-pernyataan tentang topik secara umum, selanjutnya menyempit ke topik yang akan dibahas. Berarti, paragraf pendahuluan berisi mengenai pernyataan umum dan penyataan khusus atau tesis. Paragraf isi dalam esai berisi rincian topik atau subtopik-subtopik yang sudah dinyatakan dalam kalimat tesis sebelumnya. Paragraf isi membahas satu pokok pembicaraan. Kalimat topik dalam paragraf isi sebaiknya diletakkan di awal paragraf. Paragraf penutup atau simpulan mengakhiri esai secara keseluruhan ditulis dengan harapan pembaca memperoleh pemikiran atau pandangan tersendiri mengenai topik yang dibahas. Selain itu. paragraf penutup juga biasanya ditandai dengan adanya kata transisi, seperti simpulannya, singkatnya, akhirnya, dll.

\section{HASIL DAN PEMBAHASAN}

Penelitian ini dimulai dengan pembacaan teks bacaan secara mandiri kepada mahasiswa yang menempuh pembelajaran Bahasa Indonesia pada semester gasal, teks bacaan berjudul Olahraga yang Mempersatukan Tokoh Nasional sedangkan teks berjudul KAI Antisipasi Lonjakan Pemesan Tiket Mudik diberikan kepada mahasiswa yang menempuh pada semester genap. Mahasiswa diminta membaca teks kemudian diminta membuat tulisan esai berdasarkan teks yang dibaca hingga pembelajaran usai atau \pm 60 menit. Berdasarkan data penelitian didapatkan hasil seperti pada Gambar 1. 


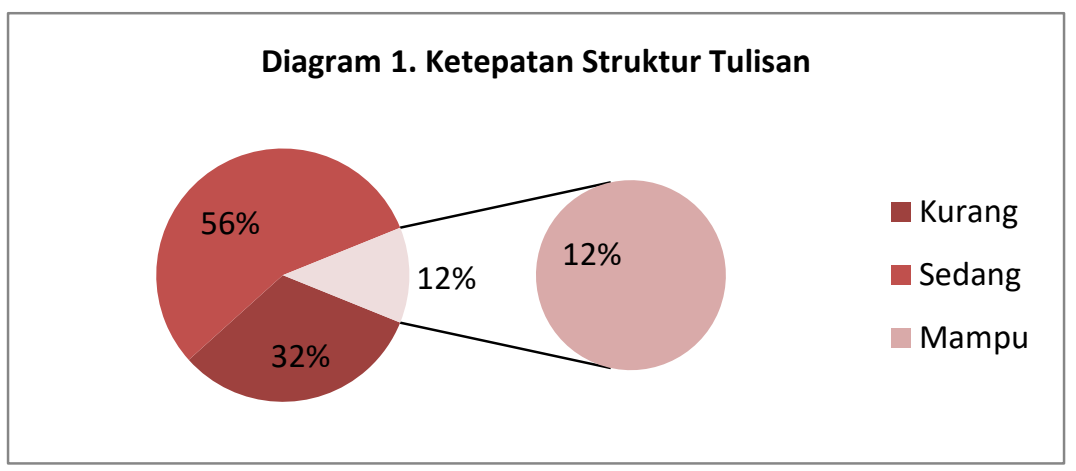

\section{Gambar 1. Ketepatan Struktur Tulisan}

Gambar 1 menunjukkan bahwa penilaian struktur tulisan dikategorikan menjadi tiga bagian: kurang, sedang, dan mampu. Tulisan esai yang dikategorikan kurang sebanyak $32.23 \%$, sedang sebanyak $55.56 \%$, dan mampu sebanyak $12.22 \%$. Berikut ini tulisan dengan kategori kurang.

Tabel 1. Rincian Penilaian Struktur Tulisan Esai

\begin{tabular}{ccccc}
\hline Skor & Nilai & Jumlah & Persentase & Kategori \\
\hline $\mathbf{0}$ & 0 & 3 & 1.67 & Kurang \\
$\mathbf{1}$ & 16.7 & 1 & 0.56 & \\
$\mathbf{2}$ & 33.3 & 54 & 30 & \\
$\mathbf{3}$ & 50 & 50 & 27.78 & Sedang \\
$\mathbf{4}$ & 66.7 & 50 & 27.78 & \\
$\mathbf{5}$ & 88.3 & 18 & 10 & Mampu \\
$\mathbf{6}$ & 100 & 4 & 2.22 & \\
\hline
\end{tabular}

Berdasarkan tabel di atas, tulisan yang dikategorikan rendah memperoleh skor bekisar 1.67-30 sebanyak 58 tulisan atau 32.2\%. Tulisan yang dikategorikan mendapatkan skor 50 sebanyak 100 tulisan atau 55.5\%. Sedangkan yang termasuk kategori mampu sebanyak 22 tulisan atau $12.2 \%$ yang mendapatkan skor berkisar 88.3-100.

Berdasarkan deskripsi diagram 1. dan tabel 1. terlihat bahwa kemampuan mahasiswa Universitas Katolik Musi Charitas tergolong sedang meskipun kategori mampu hanya $12.2 \%$ dibandingkan ketegori kurang sebesar $32.2 \%$. Penyebab munculnya ketidaktepatan tersebut dapat dikarenakan beberapa hal. Penyebab kurang tepatnya penulisan struktur tulisan antara lain seluruh tulisan berisi tesis (isi), rendahnya pemahamaman mengenai struktur tulisan, dan tidak adanya swasunting (tahapan atau prosedur menulis yang tepat).

Penyebab yang pertama yaitu seluruh tulisan berisi tesis atau isi yang disampaikan. Tulisan yang dihasilkan oleh mahasiswa masih belum menentukan topik utama yang akan dibahas. Seluruh informasi yang didapatkan dari bacaan ditulis ulang oleh mereka tanpa mengemukakan pendapat mereka sendiri. Tulisan yang dihasilkan tidak terfokus terhadap satu masalah yang akan dibahas.

Teks yang diberikan untuk mahasiswa yang menempuh Mata Kuliah Bahasa Indonesia berjudul Olahraga yang Mempersatukan Tokoh Nasional. Dalam teks tersebut, terdapat beberapa topik yang dapat dibahas dalam tulisan esai. 
Topik yang dapat dibahas antara lain kemenangan Hanifan Yudani Kusumah dalam pertandingan Pencak Silat, Persatuan yang terjalin antara Prabowo dan Jokowi atas kemenangan tim Pencak Silat, atau Pencak Silat olahraga tradisional Indonesia. Berikut dicontohkan tulisan yang memiliki topik lebih dari satu,

Esai 1

Asian Games Menyatukan Semua Orang

Kisruh politik terjadi pada saat ini memang panas. tetapi setelah Hanifan Yudani Pesilat asal Indonesia mengalahkan Pesilat asal Vietnam Thailinh Nguyen dan mendapatkan medali emas. dengan sepontan Hanifan Yudani naik ke atas tribune penonton dan memeluk Presiden Joko Widodo kemudian. memeluk ketua umum pengurus perguruan Besar Ikatan Pencak Silat Indonesia Prabowo subianto dan hanif menarik tangan Presiden Joko Widodo.

Sontak pemandangan ini mendapat tepukan hangat dari penonton dan menjadi topik utama di media sosial. setelahdi tanya oleh awak media Hanifan Yudani menjawab "saya hanya ingin melalui pencak silat, bangsa ini bisa bersatu. Terutama karena pencak silat adalah budaya bangsa”. Hanifan Yudanipun mengaku peristiwa ini terjadi secara spontan.

Presiden Joko Widodo dalam kesempatan itu banyak mengucapkan trimakasih kepada Prabowo yang telah bekerja keras mengembangkan pencak silat. Pada awalnya pencak silat hanya di targetkan empat medali emas di Asian Games 2018 dan ternyata hasilnya sangat Fantastis Indonesia mendapatkan empat medali emas. Presiden Joko Widodopun langsung memintak agar bonus kepada atlit segera di cairkan. sore itu prabowo tampak gembira "Bayangkan semua (tokoh-tokoh penting) hadir disini. di saat-saat kritis, untuk bangkitkan semangat masyarakat. kalau sudah utuk Negara dan Bangsa, kita semua bersatu Tidak ada perbedaan”, ujar prabowo. sehari sebelumnya, wapres kalla menyatakan Asian Game tidak hanya mempersatukan masyarakat tetapi juga para elite politik. "Jadi, Asian Game ini momen masyarakat kita bersatu, semua orang bersatu, tidak ada urusan partainya

\section{Esai 2}

Pencak silat yang mempersatukan Indonesia ASEAN GAMES adalah cabang olahraga yang dapat mempersatukan keberagaman diindonesia. yang terdiri dari seluruh ASIa Dalam cabang pencak silat kita berhasil mendapatkan 14 medali Emas. Dan dalam cabang pencak silat Hanifan Yudani berhasil mempersatukan tokoh Nasional. Penonton yang berada di padepoknan pencak silat Taman mini bertepuk tangan dan riuh

Reaksi tersebut mendapatkan komental baik dalam masyarakat Dan masyarakat berterimakasih kepada Hanifan karena berhasil mempersatukan tokoh. Hanifan Juga mengaku bahwa peristiwa tersebut terJadi secara spontan. Foto tersebut menjadi viral dengan waktu yang cepat 
Presiden RI berterima kasih kepada prabowo karena telah bekerja keras. Tokoh yanag memenangkan mendali mendapatkan bonus dari perintah. ASEAN Games merupakan momen penting bagi Indonesia

Esai 3

Olahraga yang Mempersatukan Tokoh Nasional

Rabu, tim pencak silat mengukir sejarah besar dengan mempersembahkan 14 medali emas bagi Indonesia. cabang ini baru pertama kali dipertandingkan di Asian Games. Salah satu atlet yaitu Hanifan Yudani Kusumah yang berumur 20 tahun berhasil mengalahkan pesilat dari Vietnam yaitu Thai Linh Nguyan. Hanifan berlari ke atas tribune utama dan langsung memeluk Presiden Joko Widodo dan ia juga memeluk Ketua Umum Penurus Ikatan Pencak Silat Indonesia Prabowo Subianto. Dan ia juga menarik lengan Jokowi dan mereka bertiga berpelukan. Sang juara dan dua tokoh yang akan bersaing pada pemilihan Presiden 2019 itu saling tersenyum dan menempelkan kepala sekitar 5 detik. Momen langka itu juga di sambut tepuk tangan dan riuh oleh penonton yang memadati Padepokan Pencak Silat Tman Mini Indonesia Indah.

Hanifan pun mengaku bahwa peristiwa itu terjadi secara spontan. Kebetulan Hanifan mendapati Jokowi dan Prabowo sekaligus dan ia juga menyelimuti tubuhnya dengan bendera merah putih. "Saya hanya ingin melalui pencak silat, bangsa ini bisa bersatu. Terutama karena pencak silat adalah budaya bangsa" kata Hanifan setelah momen pelukan bersama dua tokoh itu. Momen itu secara visual memiliki makna sangat mendalam. Foto pelukan itu juga menjadi viral di jagat maya dan mendapat. tanggapan positif dari warganet. Ketika laga itu berakhir dan para tamu beranjak pulang, Jokowi, Prabowo dan Megawati Juga bercanda di hadapan media "Saya dan Pak Prabowo tidak tahu, kok, diajak pelukan barengan. Tapi yang Jelas bau-baunya harum karena menang" kata Jokowi saat ditanya mengenai momen tersebut.

Jokowi Juga mengucapkan terima kasih kepada Prabowo yang telah bekerja keras mengembangkan pencak silat. Prabowo dan Megawati pun sempat bercanda. Sore itu, Prabowo tambak gembira karena semua tokoh penting hadir di saat-saat kritis untuk membangkitkan semangat masyarakat. kalau sudah untuk negara dan bangsa, kita semua bersatu dan tidak ada perbedaan "ujar Prabowo. Wakil Presiden Juga menyatakan Asian Games tidak hanya mempersatukan masyarakat, tetapi Juga para tokoh politik. Jadi, Asian Games ini momen masyarakat Indonesia bersatu, semua orang bersatu.

Berdasarkan esai 1, 2, dan 3 di atas, topik esai yang dijelaskan lebih dari satu hal. Pada esai 1, penulis menjelaskan mengenai kemenangan Hanifan Yudani Kusumah dalam pertandingan pencak silat, persatuan yang terjalin antara Prabowo dan Jokowi atas kemenangan tim Pencak Silat, bahkan penulis menjelaskan sedikit mengenai kekisruhan dalam kancah perpolitikan. Begitu juga esai 2, penulis memaparkan pencak silat yang berhasil mempersatukan kedua elit 
bangsa. Selain itu, ucapan terima kasih dari masyarakat karena Hanifan telah berhasil mempersatukan mereka. Paragraf terakhir berisi bonus yang didapat oleh atlet dari pemerintah RI. Pada esai 3, esai yang ditulis masih berstruktur isi saja. Isi yang dibahas meliputi Asean Games, Jokowi dan Prabowo, serta kebanggaan masyarakat akan kemenangan dan bersatunya kedua tokoh. Pembuka dan penutup esai diabaikan oleh penulis.

Selain itu, pada esai 3, mahasiswa masih menyalin ulang teks berita yang dibaca. Hal ini terlihat struktur berita yang masih nampak dalam esai yang dihasilkan. Mahasiswa masih menuliskan kembali informasi $5 \mathrm{~W}+1 \mathrm{H}$ yang ia peroleh sebelumnya. Seharusnya, dari informasi $5 \mathrm{~W}+1 \mathrm{H}$, mereka mampu menarik ide pokok atau memilih informasi yang akan dibahasnya. Ide-ide pokok yang didapatkan dari kegiatan menganalisis $5 \mathrm{~W}+1 \mathrm{H}$ itulah yang harusnya dipilih dan diubah menjadi bentuk teks dengan fokus pada satu topik dan dibantu dengan argumen-argumen yang dibuat sendiri sebagai pendukung.

Hasil analisis dari kedua validator bahwa ketiga tulisan tersebut belum memiliki struktur tulisan esai yang baik. Penulis hanya menuliskan bagian isi saja dan tidak memiliki pendahuluan dan kesimpulan esai. Berdasarkan analisis juga didapati bahwa mahasiswa belum mampu menemukan ide atau gagasan yang hendak dibahas. Mahasiswa hanya sekadar menuliskan ulang informasi yang didapat tanpa melakukan kegiatan konversi dengan tepat. Oleh sebab itu, tulisan esai yang dihasilkan mahasiswa memiliki lebih dari satu gagasan ide atau topik utama.

Idealnya, topik yang dipilih harus terfokus dengan cara memilih salah satu topik saja. Hal ini senada dengan pendapat Dalman (2014) menyatakan bahwa esai berisi sebuah gambaran opini penulis tentang subjek tertentu yang dicoba untuk dinilai mengenai satu hal yang dianggapnya perlu untuk diargumenkan. Oleh sebab itu, penulis atau mahasiswa harus menentukan terlebih dahulu topik besar yang akan dibahasnya.

Hidayah (2019) mengemukakan bahwa esai terdiri dari tiga bagian. Bagian pertama adalah pendahuluan yang berisi latar belakang informasi singkat mengenai topik yang akan dibahas. Paragraf selanjutnya berisi isi atau inti esai, inti dari pembahasan dibahas dalam paragraf ini. Paragraf terakhir berisi penutup yang membahas simpulan dari pembahasan esai.

Selain dikarenakan terlalu banyak topik yang dimuat, penyebab lainnya adalah rendahnya pemahaman penulis atau mahasiswa mengenai konsep konversi teks bacaan menjadi teks esai. Hal ini terlihat dari tulisan berikut.

Esai 4

Pendapat saya, dengan cara menambahkan pita lebar jaringan internet itu bagus karena utuk mengantisipasi lonjakan calon penumpang yang akan mengakses system pemesanan tiket. dengan adanya penambahan kapasitas bisa untuk mencegah gangguan system saat ada lonjakan pemesanan dalam waktu bersamaan. karena tahun lalu yang memesan bisa sampai satu juta orang secara bersamaan. akibatnya sistem jebol.

Menurut saya, sebaiknya PT kereta Api Indonesia tidak perlu menambah kereta api lagi pada musim lebaran tahun ini. Karena kita juga punya layanan bus trans-Jawa yang Juga sangat nyaman, apalagi sudah dibuat Jalan tol untuk bus trans-Jawa dan cepat. 
Pendapat saya. apa yang dikatakan oleh Direktur keselamatan dan keamanan KAI Apriyono wedI chresnanto Itu sangat bagus. karena untuk menJaga keselamatan dan kenyamanan perjalanan. KAI akan menyiagakan petugas yang terdiri dari 1.556 TNI/polri. 1.564 Polsuska dan 7.500 petugas keamanan dan Juga menempatkan petugas di daerah rawan banJir, lonsor dan ambles. Jadi dengan cara ini kemungkinan perjalanan menggunakan kereta Api Indonesia bisa aman dan selamat sampai tuJuan.

Esai 5

1. Paragraf 2 (dua) mengatakan bahwa Pihak dari Direktur Utama PT KAI telah meningkatkan kapasitas pita lebar hingga dua kali lipat dari 200 megabita menjadi 400 megabita

2. Paragraf ke lima membahas bahwa Jumlah kursi yang disediakan oleh KAI pada saat mudik lebaran jauh lebih meningkat 5 persen dari tahun 2018.

3. Paragraf ke enam mebahas bahwa

Jumlah kereta yang dioperasionalkan oleh pihak KAI meningkat menjadi 3 persen dari tahun yang sbelumnya.

Berdasarkan esai 4 dan 5 di atas, teks yang dihasilkan lebih terlihat seperti keterampilan berbicara yang ditranskripkan ke dalam bentuk tulisan. Penulis menuliskan pendapatnya tetapi tidak mengemasnya ke dalam esai yang baik. Menurut Emmitt dan Pollock (dalam Priyanti \& Triwidayati, 2017) menyatakan bahwa keterampilan berbicara dan menulis merupakan dua hal yang berbeda meskipun kedua keterampilan tersebut terdapat kesamaan. Kedua keterampilan tersebut menghasilkan atau memproduksi informasi. Namun, perbedaan terletak dari proses penyampaiannya.

Dalam keterampilan berbicara, semua hal yang berkaitan dengan apa yang akan disampaikan diinformasikan pada waktu yang bersamaan. Sedangkan dalam keterampilan menulis, produksi hal itu harus dilakukan secara detail, sehingga menuntut perencanaan dan membutuhkan adanya berbagai revisi. Sehingga ketika kegiatan menulis dilakukan, penulis harus memiliki kesiapan dan kemampuan yang memadai. Berdasarkan temuan di atas menunjukkan bahwa penulis belum memahami konsep dasar dari struktur penulisan esai.

Selain mahasiswa belum memahami konsep struktur esai, rendahnya pemahaman akan konsep struktur sebuah tulisan atau esai juga terjadi. Hal ini didukung dengan hasil posttest yang telah dilakukan setelah pembelajaran Mata Kuliah Bahasa Indonesia selesai bahwa adanya peningkatan yang cukup signifikan pada penulisan atau penentuan struktur tulisan esai. Ketika proses perkuliahan, mahasiswa kembali berdiskusi membahas mengenai esai termasuk struktur esai. Mahasiswa diminta mengonversi kembali bacaan menjadi teks esai.

Konsep pembelajaran yang dilakukan sudah mengarah kepada pembelajaran literasi. Konsep pembelajaran tersebut mengharapkan mahasiswa memiliki kemampuan dalam berliterasi. Konsep pembelajaran menulis tidak hanya memberikan tugas tetapi ikut membimbing dalam proses menulis mahasiswa. Hal ini sesuai dengan pendapat Abidin, dkk. (2017) bahwa peran pendidik dalam pembelajaran menulis bukanlah sebagai seorang pengajar saja tetapi sebagai 
seorang pembimbing dalam proses pembelajaran. Hal ini memungkinkan bahwa selama ini, mahasiswa ketika kegiatan menulis pada jenjang pendidikan sebelumnya tidak dibimbing oleh pendidik akibatnya tulisan yang dihasilkan belum sesuai dengan yang diharapkan.

Hal ini juga terkait dengan penyebab ketiga. Kebiasan yang tidak tepat terjadi ketika mahasiswa menulis. Salah satu penyebabnya adalah latar belakang pendidikan mereka sebelumnya yang tidak membiasakan kegiatan atau proses menulis dengan benar.

Proses kegiatan menulis yang dilakukan oleh mahasiswa tanpa menerapkan langkah-langkah atau tahapan dalam menulis yang benar. Tidak heran, tulisan yang dihasilkan masih memiliki banyak kekurangan. Seharusnya kegiatan menulis harus sesuai dengan prosedur kegiatan menulis. Hal ini terlihat dari tulisan berikut,

Esai 6

Menurut saya antisipasi Lonjakan pemesanan tiket mudik di PT kereta Api Indonesia (persero) sudah sangat baik mereka sudah berusaha untuk meningkatkan kapasitas pita lebar hingga dua kali Lipat dari 200 megabita menjadi 400 megabita untuk mencegah seketika ada Lonjakan pemesanan dalam waktu bersamaan. namun akan tetapi penambahan kereta baru bisa dilakukan sepanjang ada sarana yang pendeukungnya. Tapi kata Edi saya tidak tahu apakah bisa siap sebelum Lebaran.

Seharusnya mereka sudah siap menurut menteri perhubungan Budi karya samadi menyampaikan saat ini persiapan angkutan Lebaran sudah dimulai saat ini mereka sudah mempunyai Layanan KAI yang bagus. Apalagi ada tol Trans-Jawa JAdi menggunakan bus akan sangat nyaman dan cepat.

Mereka Juga sudah menempatkan petugas di daerah rawan banjir, longsor dan amblas. Juga menambah petugas penjaga pintu perLintasan yang rawan kecelakaan dan tugas pemeriksaan Jalur.

\section{Esai 7}

\section{Olahraga yang Mempersatukan Tokoh Nasional}

Setelaha mengalahkan pesilat Vietnam, Thai Linh Nguyen, Hanifan Yudani. Kusumah (20) berlari ke atas tribune utama.dan. memeluk Presiden.Joko.Widodo. lalu, ia memeluk.Ketua Umum. Pengurus Besar.Ikatan Pencak Silat Indonesia Parbowo Subianto. Tiba-tiba; Hanifan menarik.lengan Jokowi. dan mereka bertiga berpelukan.

Selama sekitar 5 detik, sang .juara dan.dua tokoh yang.akan.bersaing.pada pemilihan Presiden 2019 Itu saling menempelkan.kepala.da.tersenyum. momen langka itu disambut tepuk tangan dan riuh penonton yang memadati Padepokan.pencak.silat Taman.Mini Indonesia Indah, Jakarta Timur, Rabu (2019/8/2018). Teriakan."Indonesia...Indonesia". terus membahana.dari .tribune penonton.

Tokoh lain, seperti .Wakil .Presiden Jusuf. Kalla, presiden kelima RI Megawati Soekarno. Putri, Menko Pembangunan. Manusia dan. Kebudayaan Puan Maharani, dan Ketua Kontingen Indonesia 
yang Juga. Menteri Pendayagunaan . Aparatur .Negara.Syarifuddin, yang hadir menonton laga. Final pencak silat kategori tanding kelas.C putra Asian Games 2018 itu juga berdiri dan bertepuk .tangan.

Rabu; tim pencak silat mengukir.sejarah besar dengan. mempersembahkan14 medali emas bagi Indonesia. Cabang ini baru.pertama.kali dipertandingkan di Asian Games. "saya.hanya ingin, melalui.pencak silat; bangsa ini bisa bersatu. Terutama karena pencak silat. adalah. budaya bangsa," kata Hanifan setelah.momen .pelukan bersama .dua tokoh Itu.

Hanifan pun .mengaku bahwa pristiwa Itu terjadi .secara spontan. Keberulan Hanifan .mendapati Jokowi dan Prabowo sekaligus. Kebetulan pula. Hanifan menyelimuti gubuhnya dengan bendera Merah Putih. Momen i.tu secara visual memiliki .makna .sangat mendalam.

Tulisan di atas menunjukkan bahwa mahasiswa tidak melakukan tahapan kegiatan menulis yang baik. Hasil tulisan mahasiswa tersebut tidak memperhatikan kegiatan pramenulis. Mahasiswa belum menentukan konsep atau ide yang akan dikembang menjadi tulisan tersebut. Selain itu, tulisan mahasiswa tersebut tidak melakukan swasunting (pascamenulis).

Dalam kegiatan pascamenulis, mahasiswa dapat melakukan pembacaan ulang tulisan. Ketika melakukan pembacaan tulisan ulang, mahasiswa akan melihat kesalahan-kesalahan yang dilakukan ketika proses menulis, baik kurang tepatnya struktur hingga kebahasaannya.

Kesalahan pertama dalam tulisan tersebut berupa konsep esai. Mahasiswa masih mencampurkan konsep menulis dan berbicara. Hal ini terlihat dari penggalan pertama paragraf yang dimulai dengan frase Menurut saya. Pada akhir paragraf tersebut pun, tulisan berisi kutipan pernyataan dari teks bacaan tetapi tanpa melengkapi unsur kebahasaan dalam menulis, seharusnya tulisan tersebut diubah menjadi kalimat langsung atau tidak langsung.

Selain itu, tulisan tersebut tidak tepat dalam penyusunan struktur tulisan esai. Tulisan tersebut terdiri dari isi-penutup-isi. Paragraf kedua berisi saran yang merupakan bagian dari penutup esai. Selanjutnya, paragraf ketiga berisi thesis atau argument kembali mengenai isi paragraf pertama.

Kegiatan menulis dalam konteks literasi harus dilakukan dengan menggunakan prosedur menulis yang tepat. Dorn dan Soffos (dalam Abidin, dkk, 2017) mengemukakan prosedur kegiatan menulis antara lain tahap pramenulis, berupa penentukan konsep atau ide yang akan dikembang menjadi tulisan, tahap menulis berupa pembentukan kerangka karangan dan langsung dikembangkan menjadi sebuah tulisan, dan yang terakhir tahap pascamenulis berupa pembacaan ulang tulisan, penyuntingan, dan diakhiri dengan publikasi hasil. Hal ini senada dengan pendapat Dibia (2016) bahwa dalam menulis terdapat tiga tahapan antara lain, tahap persiapan, penulisan, dan penyuntingan. Tahap persiapan dilakukan bertujuan menemukan masalah yang akan dibahas. Persiapan yang dapat dilakukan dalam mengonversi teks berita menjadi esai dapat melalui informasi $5 \mathrm{~W}+1 \mathrm{H}$. Tahap menulis dilakukan untuk mengembangkan konsep awal informasi yang diperoleh. Informasi yang sudah ditentukan akan ditulis dibahas secara rinci dan detail. Tahap terakhir, tahap penyuntingan. Menyunting tulisan menjadi 
bagian dalam menulis. Penyuntingan esai dapat dilakukan dalam memeprbaiki ejaan atau tanda baca, unsur kebahasaan, struktur esai, hingga spesifikasi atau ketepatan topik yang dipilih. Tahap penyuntingan.

Nirmawan (2017) mengemukakan pendapat bahwa selain struktur kebahasaan, penyuntingan dilakukan untuk memperhatikan ejaan, tanda baca, pilihan kata, keefektifan kalimat dan ketepatan paragraf sehingga memperoleh suntingan yang baik. Penyuntingan dilakukan untuk mendapatkan tulisan yang baik dan benar secara ketatabahasaan dan bernalar. Lanjutnya, penyunting yang baik harus mampu melihat teks tulisan yang benar, kohesi, dan koherensi yang tepat. Setelah tahap penyuntingan dilakukan, penulis akan menghasilkan tulisan yang baik. Tulisan yang dihasilkan oleh mahasiswa terlihat bahwa mereka mengabaikan tahap pramenulis dan pascamenulis. Tulisan dihasilkan tanpa proses penentukan konsep atau ide, pembacaaan ulang hasil tulisan, bahkan tanpa penyuntingan. Hal ini terlihat dari beberapa tulisan yang dihasilkan masih banyak kesalahan ejaan atau penggunaan tanda baca yang tidak tepat. Hal tersebut terlihat dalam teks esai 7.

Penyebab-penyebab terjadinya kesalahan dalam penulisan esai dapat diperbaiki melalui pendekatan pembelajaran menulis dengan tepat. Penyebab terbesar terjadinya kesalahan karena pembiaran yang dilakukan pendidik sebelumnya. Berdasarkan hasil penelitian yang dilakukan oleh Lie, dkk (2018) bahwa dari keenam kota yang tersebar di Indonesia, guru-guru bahasa dalam hal ini Bahasa Indonesia dan Bahasa Inggris memiliki kompetensi menulis yang masih di bawah standar. Dalam bidang Bahasa Indonesia, hasil penelitian menunjukkan bahwa,

Hasil tes menulis guru SMP: nilai terendah 5,5 dan nilai tertinggi 100. Sejumlah 47,5\% guru SMP mampu mengerjakan soal atau memiliki tingkat pemahaman bacaan yang cukup. Sedangkan guru bahasa Indonesia tingkat SMA, sejumlah 65\% mampu mengerjakan soal atau memiliki tingkat pemahaman bacaan yang cukup. Dengan demikian dapat dinyatakan bahwa tingkat pemahaman bacaan yang berada pada kategori cukup sebesar 56,2\% dari total guru yang diteliti. Sedangkan 43,8 guru bahasa Indonesia tingkat SMP dan SMA yang diteliti tingkat pemahaman bacaannya kurang.

Tidak heran, jika dengan tingkat pemahaman di bawah $60 \%$ agak sulit bagi pendidik untuk menginformasikan atau melakukan pembelajaran menulis dengan tepat. Salah satu solusi yang dapat dilakukan adalah guru melakukan pembelajarn menulis dengan menggunakan konsep pembelajaran dasar literasi menulis.

Pembelajaran dasar literasi menulis berbeda dengan pembelajaran menulis pada umunya. Pembelajaran literasi menulis menuntut peserta didik melakukan proses menulis secara berulang-ulang untuk merevisi ide-idenya, mengulangi setiap proses kegiatan menulis sehingga mampu mengaplikasikan kemampuan menulis secara maksimal. Secara umum, pembelajaran literasi menulis memiliki tahapan yang sama dengan tahapan menulis pada umunya. Hal yang membedakannya, tahapan dalam pembelajaran literasi menulis lebih spesifik dibandingkan kegiatan menulis pada umumnya. Pembelajaran literasi menulis dimulai dari pemerolehan ide, pengolahan ide, pemroduksian ide, penyuntingan, dan publikasi (Abidin dkk, 2017). 
Tahap pertama pemerolehan ide. Dalam tahap ini, peserta didik harus mampu mereaksi berbagai fenomena yang sedang terjadi. Berbagai fenomena dapat diperoleh melalui berbagai hal termasuk keterampilan daya tanggap akan fenomena hidup. Tahap kedua, pengolahan ide. Dalam tahap ini, peserta didik dituntut menggali ide dengan cara menggali kemampuan berpikir. Kemampuan berpikir diharapkan dapat menghasilkan tulisan yang sesuai dengan nalar, logis, dan memenuhi ciri sebuah tulisan keilmuan. Tahap ketiga, pemroduksian ide dalam tahap ini, peserta didik harus mampu menggunakan kemampuan memproduksi bahasa yang dimilikinya. Dari kemampuan memroduksi bahasa, peserta didik dituntut mampu mengemas gagasan yang telah diolah sebelumnya. Melalui pengetahuan dan kemampuan mengemas bahasa ini, tujuan kegiatan menulis akan dituju sesuai dengan genre atau tujuan awal penulisan. Tahap selanjutnya, penyuntingan. Peserta didik akan menilai tulisan yang telah dihasilkan olehnya. Penilaian yang dilakukan dengan memperhatikan isi, kebenaran bahasa, hingga teknik penulisannya. Dalam tahap penyuntingan ini juga, penulis dapat melakukan pembacaan profesional melalui orang lain yang memiliki keilmuan sebidang. Tahap terakhir adalah publikasi. Dalam tahap publikasi ini, peserta didik dapat mempublikasikan tulisan melalui media, baik media cetak ataupun online.

Dalam proses pembelajaran literasi menulis, peserta didik diharapkan memiliki kemampuan menulis dalam bentuk berbagai genre teks sesuai dengan tujuan, sasaran baca, ataupun konteks keilmuan ataupun sosial budaya. Kemampuan menulis melalui berbagai genre teks didapatkan setelah peserta didik memiliki pengetahuan macam-macam tulisan. Kemampuan menulis harus memerlukan praktik. Menurut Susanto Leo, keterampilan atau kemampuan menulis bukanlah bakat atau kemampuan yang dihasilkan dari keturunan. Melainkan keterampilan yang akan ada jika melalui latihan, sebab seberapa besar bakat seseorang untuk menulis jika tidak dilatih maka tidak akan berkembang (Nugraheni, 2017).

Banyak cara atau metode yang dapat digunakan dalam pembelajaran literasi menulis, terkhusus dalam mengonversi teks bacaan. Pendidik dapat menggunakan beberapa metode. Salah satu metode tersebut adalah metode menulis berbasis genre (Genre-Based Writing). Genre Based Writing atau yang dikenal dengan menulis berbasis teks menekankan pembelajaran pada pentingnya pemahaman sebuah teks sebagai bekal kegiatan menulis. Secara umum, siklus pembelajaran menulis berbasis genre dimulai dengan membangun teks, pemodelan, menyusun teks secara bersama, dan menyusun teks secara mandiri.

\section{SIMPULAN}

Berdasarkan uraian di atas, simpulannya bahwa kemampuan penggunaan struktur tulisan esai mahasiswa Universitas Katolik Musi Charitas masih dapat dikategorikan sedang. Hal ini dibuktikan dengan hasil penilaian sebesar $32.23 \%$ dikategorikan masih rendah, sedang sebanyak $55.56 \%$, dan mampu sebanyak $12.22 \%$. dalam hal ini, tulisan mahasiswa masih yang hanya terdiri dari struktur isi tanpa pembuka dan penutup, pembuka dan isi tanpa penutup, atau bahkan isi dan penutup tanpa pembuka. Hal tersebut dikarenakan beberapa hal antara lain, ketidakpahaman mereka mengenai struktur tulisan, rendahnya pemahamaman mengenai struktur tulisan, dan tidak adanya swasunting (tanpa adanya prosedur penulisan yang tepat). Pembiasaan prosedur menulis yang tepat dan kegiatan 
literasi membaca yang dapat digalakkkan akan mampu membantu memperbaiki kualitas tulisan. Selain itu, pendidik juga dapat menggunakan berbagai metode dalam pembelajaran menulis, salah satunya Genre Based Teks.

\section{UCAPAN TERIMA KASIH}

Artikel ini merupakan bagian dari hasil penelitian Representasi Literasi Menulis Mahasiswa Universitas Katolik Musi Charitas yang didanai oleh Kemenristekdikti pada skema Penelitian Dosen Pemula (PDP), tahun pendanaan 2019. Penelitian ini diketuai Tresiana Sari Diah Utami, M.Pd. (Universitas Katolik Musi Charitas). Anggota penelitian ini adalah Katarina Retno Triwidayati, M.Pd. (Universitas Katolik Musi Charitas).

\section{DAFTAR PUSTAKA}

Abidin, Y., Mulyati, T., \& Yunansah, H. (2017). Pembelajaran Literasi Strategi Meningkatkan Kemampuan Literasi Matematika, Sains, Membaca, dan Menulis. Jakarta: Bumi Aksara.

Afifuddin, B. A. S. \& Saebani, B. A. (2009). Metodologi Penelitian Kualitatif. Bandung: Pustaka Setia.

Aji, F. T. (2013). Perilaku Plagiarisme di Kalangan Mahasiswa Magister Universitas Airlangga. Thesis Fakultas Ilmu Sosial dan Ilmu Politik Unair. Diakses dari http://repository.unair.ac.id/, diunduh pada tanggal 22 April 2020, pada pukul 12.30 WIB.

Dalman. (2014). Menulis Karya Ilmiah. Jakarta: Raja Grafindo.

Dibia, I. K., \& Dewantara, I. P. M. (2016). Bahasa Indonesia untuk Perguruan Tinggi. Depok: Rajawali Pers.

Fitriyani. (2016). Kemampuan Menulis Esai Siswa Kelas XII SMA Negeri 9 Bandar Lampung Tahun Ajaran 2011/2012. Skripsi Unila. Diakses dari http://digilib.unila.ac.id/, diunduh pada tanggal 21 Agustus 2019, pada pukul 10.46 WIB.

Hasnadi. (2019). Membangun Budaya Literasi Informasi Pada Perguruan Tinggi. Seminar Nasional Multi Disipin Ilmu UNAYA, 3(1), 610 - 620.

Havana. (2014). Analisis Kemampuan Literasi Digital Penulis Artikel di Website PT. Nyunyu Digital Media Jakarta. Jurnal Ilmu Perpustakaan, 5(3), 311 320.

Hidayah. (2019). Panduan Menulis Esai. Diakses dari https://osf.io, diunduh pada tanggal 6 November 2019, pada pukul 15.15 WIB.

Hidayanto, A. (2019). Panduan dalam Menulis Esai. Diakses dari http://staff.ui.ac.id/, diunduh pada tanggal 21 Agustus 2019, pada pukul 10.46 WIB.

Lie, A., dkk. (2018). Laporan Pemetaan Kompetensi Guru Bahasa Indonesia dan Bahasa Inggris. Surabaya: Universitas Widya Mandala.

Nugraheni, A. S. (2017). Bahasa Indonesia di Perguruan Tinggi Berbasis Pembelajaran Aktif. Jakarta: Prenada Media.

Mariana, I. (2013). Pengaruh Pendekatan Writing Process terhadap Kemampuan Menulis Narasi Ekspositoris dan Kreativitas Bahasa Tulis Siswa. Skripsi UPI. Diakses dari http://repository.upi.edu/, diunduh pada tanggal 20 Maret 2020, pada pukul 20.00 WIB. 
Mulyaningsih, I., Suwandi, S., Setiawan, B., \& Rohmadi, M. (2016). Model Pembelajaran Menulis Ilmiah Berbasis PARMI (Produksi, Atensi, Retensi, Motivasi, dan Inovasi) \& Penerapannya. Cirebon: CV. Confident.

Muslimin. (2018). Menumbuhkan Budaya Literasi dan Minat Baca dari Kampung. Diakses dari repository.ung.ac.id, diunduh pada 20 Agustus 2019, pukul 07.46 WIB.

Nirmawan. (2017). Kemampuan Menyunting Karangan Eksposisi Berdasarkan Ejaan, Pilihan Kata, dan Keterpaduan Paragraf Siswa Kelas VII SMP Muhammadiayah 06 Medan Tahun Ajaran 2016-2017. Jurnal Penelitian Pendidikan Bahasa dan Sastra, 2(1), 156 - 160.

Pusat Pembinaan Badan Pengembangan dan Pembinaan Bahasa Kementerian Pendidikan dan Kebudayaan. (2016). Pedoman Gerakan Nasional Literasi Bangsa. Diakses dari gln.kemdikbud.go.id/, diunduh pada tanggal 20 Maret 2019, pada pukul 13.42 WIB

Priyanti, A. M., \& Triwidayati, K. R. (2017). Bentuk Penerapan Budaya Literasi Bagi Calon Guru Sekolah Dasar di Universitas Katolik Musi Charitas Palembang. Jurnal PGSD Musi, 1(2), 77 - 90.

Widiastuti, A. (2020). Data, Teknik Pengumpulan Data dan Instrumen Penelitian. Diakses dari http://staff.uny.ac.id/, diunduh pada tanggal 30 April 2020, pada pukul $12.00 \mathrm{WIB}$.

Wijayanti, S. H., Candrayani, A., Hendarwati, I. E. S., \& Agustinus, J. W. (2015). Bahasa Indonesia Penulisan dan Penyajian Karya Ilmiah. Jakarta: Rajawali Pers.

Yaumi. (2017). Penerapan Perangkat Model Discovery Learning pada Materi Pemanasan Global untuk Melatihkan Kemampuan Literasi Sains Siswa SMP Kelas VII. E-Journal Pensa, 05(01), 38 - 45. 